\title{
METODOLOGI EKONOMI ISLAM
}

\author{
Yasmansyah Yasmansyah ${ }^{\bowtie}$, Zulfani Sesmiarni
}

Institut Agama Islam Negeri (IAIN) Bukittinggi, Indonesia

yasmasnyahsagmpd@gmail.com, zulfanisesmiarni@iainbukittinggi.ac.id

https://doi.org/10.46367/iqtishaduna.v10i2.424

Received: Oct 29, 2021 Revised: Des 01, 2021 Accepted: Des 07, 2021 Published: Des 17, 2021

\begin{abstract}
This study aims to analyze the thinking methods used in Islamic economics critically. This study assumes that the methods used in Islamic economics are mostly designed to determine Fallah. Islamic economics was born not as a separate discipline but as an integral part of the Islamic religion as complete life teaching. Islam guides all human activities, including economics. This research is library research with a qualitative approach. Sources of data in this study using secondary data derived from books and relevant research results. The results of this study found that the methodology of Islamic economics must be built on the principles of Islamic epistemology, produce scientific criteria, and convey Islamic values to others. Islamic economics has a complete scientific building, giving birth to theories that explain economic doctrine and reality.
\end{abstract}

Keywords: Methodology, Economics, Islamic Economics.

\begin{abstract}
ABSTRAK
Tujuan penelitian ini adalah untuk menganalisis metode berpikir yang digunakan dalam ekonomi Islam secara kritis. Penelitian ini mengasumsikan bahwa metode yang digunakan dalam ekonomi Islam sebagian besar didesain untuk menentukan fallah. Ekonomi Islam lahir bukanlah sebagai suatu disiplin ilmu tersendiri, melainkan berbagai integral dari agama Islam sebagai ajaran hidup yang lengkap. Islam memberikan petunjuk terhadap semua aktivitas manusia, termasuk ekonomi. Penelitian ini merupakan penelitian kepustakaan dengan pendekatan kualitatif. Sumber data dalam penelitian ini menggunakan data sekunder yang berasal dari buku dan hasil penelitian relevan. Hasil penelitian ini mendapatkan bahwa metodologi ekonomi Islam harus dibangun berdasarkan prinsip epistemologi Islam, melahirkan kriteria ilmiah, dan dapat menyampaikan nilainilai Islami kepada orang lain. Ekonomi Islam memiliki bangunan keilmuan lengkap, melahirkan teori yang menjelaskan doktrin dan realitas ekonomi.
\end{abstract}

Kata Kunci: Metodologi, Ekonomi, Ekonomi Islam.

\section{PENDAHULUAN}

Ekonomi merupakan bagian yang tidak terpisahkan dari ajaran Islam, karena hakikatnya ajaran Islam bersifat syumuliyah, yaitu mencakup seluruh bidang kehidupan. Mark Blaugh mencatat bahwa pada tahun 1970-an adalah maraknya diskusi metodologi ekonomi sehingga metodologi ekonomi sudah layak 
disebut sebagai sub-disiplin ilmu ekonomi karena keteraturan kerangka kajiannya (Furqani 2018, 29). Ketertarikan untuk mengkaji metodologi dikalangan pemikir ekonomi disebabkan maraknya diskusi tentang filsafat ilmu. Hal ini mendorong mereka untuk memikirkan kembali hakikat ilmu ekonomi, cakupan kajiannya dimensi-dimensi ilmiahnya serta teori ekonomi yang lebih bisa menjelaskan realitas. Kondisi saat ini, dinamika diskusi metodologi dimarakkan dengan kemunculan mazhab heterodoks yang secara fundamental mempertanyakan kembali prinsip-prinsip dasar ilmu ekonomi, asumsi yang dianut dalam mengembangkan teori serta pendekatan yang digunakan dalam menghasilkan teori ekonomi. Gerakan pemikiran ekonomi heterodoks berusaha mengembangkan ilmu ekonomi yang dapat melihat realitas ekonomi dalam perspektif yang lebih besar sehingga sebuah disiplin ilmu ekonomi yang sejati dapat dilahirkan (Furqani 2018, 30).

Ekonomi Islam sebagai sebuah disiplin ilmu masih dalam proses perkembangan. Para ilmuwan masih terus mengkaji elemen-elemen ilmiah, landasan filsafat, metodologi dan subtansi ilmu ekonomi Islam. Sasaran yang ingin dicapai dalam dua aspek, pertama dalam tataran ilmiah melahirkan konsep, teori dan kerangka ilmu ekonomi Islam sebagai sebuah body of knowledge dan kedua dalam tataran praktik mewujudkan sistem ekonomi Islam yang akan mengaplikasikan doktrin dan prinsip Islam tentang ekonomi ke alam realita. Ekonomi Islam kontemporer lahir sebagai jawaban ilmuwan Muslim kontemporer terhadap permasalahan ilmiah kontemporer dalam bidang ekonomi yang dinilai tidak mampu memberikan jawaban yang seutuhnya terhadap permasalahan hidup manusia modern (Furqani 2018, 1). Untuk memahami hubungan antara agama dan perilaku ekonomi maka harus dipelajari bidang dan lingkup masing-masing. Secara umum agama (religion) diartikan sebagai persepsi dan keyakinan manusia terkait dengan eksistensinya, alam semesta, dan peran Tuhan terhadap alam semesta dan kehidupan manusia sehingga membawa kepada pola hubungan dan perilaku manusia dengan Tuhan, sesama manusia dan alam semesta.

Islam mendefinisikan agama bukan hanya berkaitan dengan spiritual atau ritualitas, namun agama merupakan serangkaian keyakinan, ketentuan dan peraturan serta tuntutan moral bagi setiap aspek kehidupan manusia. Ekonomi secara umum didefenisikan sebagai hal yang mempelajari perilaku manusia dalam menggunakan sumber daya yang langka untuk memproduksi barang dan jasa yang dibutuhkan manusia. Dengan demikian ekonomi merupakan suatu bagian dari agama. Ruang lingkup ekonomi meliputi satu bidang perilaku manusia terkait dengan konsumsi, produksi dan distribusi. Setiap agama secara definitif memiliki pandangan mengenai cara manusia berperilaku mengorganisasi kegiatan ekonominya. Meskipun demikian, mereka berbeda dalam intensitasnya (P3EI 2009, 13-14).

Penelitian ini bertujuan untuk meneliti metode berpikir (logika) yang digunakan dalam ekonomi Islam secara kritis. Penelitian ini mengasumsikan bahwa metode yang digunakan dalam ekonomi Islam sebagian besar didesain untuk menentukan fallah. Ekonomi Islam merupakan ilmu sosial, seperti halnya ilmu sosial lainnya, unit analisis yang tepat untuk ekonomi Islam adalah masyarakat. Oleh sebab itu metodologi ekonomi Islam lebih fokus pada fenomena ekonomi dan dapat berubah dari waktu ke waktu dan dari suatu masyarakat ke 
yang lain. Ekonomi Islam dalam usaha mengetahui suatu kebenaran harus menggunakan metodologi yang tepat atas sifat sosial dan deskriptifnya.

\section{TELAAH LITERATUR}

\section{Metode dan Metodologi}

Menurut bahasa (etimologi), metode berasal dari bahasa Yunani, yaitu meta (sepanjang), hodos (jalan). Jadi metode adalah suatu ilmu tentang cara atau langkah-langkah yang ditempuh dalam suatu disiplin tertentu untuk mencapai tujuan tertentu. Metode berarti ilmu cara menyampaikan sesuatu kepada orang lain. Metode juga disebut pengajaran atau penelitian. Sedangkan menurut istilah (terminologi), metode adalah ajaran yang memberi uraian, penjelasan dan penentuan nilai. Metode biasa digunakan dalam penyelidikan keilmuan. Hugo F. Reading mengatakan bahwa metode adalah kelogisan penelitian ilmiah, sistem tentang prosedur dan teknik riset (Nahriyah 2018).

Ketika metode digabungkan dengan kata logos maknanya berubah. Logos berarti "studi tentang". Oleh karena itu metodologi tidak lagi sekedar kumpulan cara yang sudah diterima (well reseived) tetapi berupa kajian tentang metode. Dalam metodologi dibicarakan kajian tentang cara kerja ilmu pengetahuan. Pendek kata, bila dalam metode tidak ada perbedaan, refleksi dan kajian atas cara kerja ilmu pengetahuan. Sebaliknya dalam metodologi terbuka luas untu mengkaji, mendebat, dan merefleksi cara kerja suatu ilmu. Maka dari itu, metodologi menjadi bagian dari sistematika filsafat, sedangkan metode tidak (Fanani 2008, 9).

Sedangkan menurut Partanto and Al-Barry $(1994,462)$ metodologi adalah ilmu cara-cara dan langkah-langkah yang tepat (untuk menganalisa sesuatu) penjelasan serta menerapkan cara. Metode didefinisikan sebagai suatu rangkaian sistematik dan urutan ide (pemikiran). Hal ini merujuk pada suatu struktur berpikir seperti induksi atau deduksi atau teknik penelitian atau alat-alat yang digunakan untuk mengumpulkan data seperti observasi, studi kasus, atau survey. Metode merupakan suatu mode, prosedur atau cara investigasi berdasarkan suatu rencana yang ditentukan. Metode mengarahkan kita bagaimana merangkai ide, opini, dan argument untuk menginvestigasi atau menjelaskan suatu kebenaran. Sedangkan metodologi merupakan filosofi penelitian. Metodologi menentukan pendekatan yang diambil oleh peneliti untuk memahami fenomena-fenomena terentu. Metodologi juga menentukan standar-standar diterimanya suatu kejadian dan menentukan peran berpikir di dalam investigasi. Metodologi merupakan suatu ilmu mengenai metode-metode dan pengaplikasiannya pada bidang tertentu. Metodologi melibatkan ketepatan metode-metode dan teknik-teknik berpikir yang digunakan di dalam suatu investigasi.

\section{Metodologi Ilmu Ekonomi dalam Islam}

Menurut Hassan (1998) ada dua pendekatan metodologi yang digunakan dalam membangun ilmu ekonomi. Pertama, all-or-nothing approach yaitu pendekatan yang berpegang pada prinsip "syariah total atau tidak syariah sama sekali" maksudnya adalah seluruh teori dan konsep ekonomi konvensional dinegasikan dan diruntuhkan, kemudian dibangunlah ilmu ekonomi Islam dengan definisi dan konseptualisasinya sendiri. Akan tetapi, kelemahan pendekatan ini 
seringkali tidak aplikatif dan sulit di realisasikan. Kedua, step by step approach yaitu pendekatan gradual maksudnya pendekatan ini terjadi proses filterisasi ilmu ekonomi konvensional dengan mengeliminasi komponen-komponen yang bertentangan dengan ajaran Islam. Namun kelemahan pendekatan ini adalah munculnya kritik bahwa ekonomi Islam hanya "mengekor" ekonomi konvensional semata, sehingga original keilmuannya sering dipertanyakan (Beik 2016).

Metodologi ekonomi Islam akan menjelaskan kriteria ilmiah untuk melahirkan teori ekonomi Islam yang sesuai dengan sumber pengetahuan yang diakui dalam epistemologi Islam. Dalam hal ini menurut Al-Attas (1993) yang menjadi tantangan adalah bagaimana melahirkan metodologi yang tepat sehingga kita dapat melahirkan ilmu yang benar dan menghindari kecacatan atau kesalahan dalam proses ilmiah dalam timbangan epistemologi Islam sebagaimana yang terjadi dalam tradisi ilmiah Barat akibat sekularisasi dan reduksi dalam metodologi ilmiah mereka (Furqani 2018, 32).

Ekonomi Islam sebenarnya telah muncul sejak Islam itu dilahirkan. Ekonomi Islam lahir bukanlah sebagai suatu disiplin ilmu tersendiri melainkan berbagai integral dari agama Islam. Sebagai ajaran hidup yang lengkap, Islam memberikan petunjuk terhadap semua aktifitas manusia, termasuk ekonomi. Sejak abad ke 8 telah muncul pemikiran-pemikiran ekonomi Islam secara parsial, misalnya peran negara dalam ekonomi, kaidah berdagang, mekanisme pasar, dan lain-lain, tetapi pemikiran secara komprehensif terhadap sistem ekonomi Islam sesunguhnya baru muncul pada pertengahan abad ke 20 dan semakin marak sejak dua dasawarsa terakhir (P3EI 2009, 17). Metodologi ekonomi telah menjadi bahan kajian yang diminati oleh para ekonom, khususnya di tengah-tengah krisis ilmu ekonomi saat ini. Diskusi yang berkembang tidak saja berkisar kepada mengkritik metodologi logika positivisme seperti yang dipakai oleh ekonomi neoklasik yang saat ini mendominasi ilmu ekonomi, tetapi juga mencoba melihat struktur keilmuan ekonomi secara keseluruhan. Banyak perspektif alternatif telah diajukan untuk menjawab berbagai kekurangan dalam metodologi ilmu ekonomi (Furqani 2018, 28-29).

\section{METODE PENELITIAN}

Penelitian ini merupakan penelitian kepustakaan (library research) dengan pendekatan kualitatif. Nazir (1988) mengungkapkan penelitian kepustakaan merupakan suatu cara pengumpulan data dengan menelaah buku, catatan, literatur, serta berbagai laporan yang sesuai dengan masalah yang ingin dipecahkan (Sari and Asmendri 2020). Zed (2008) menyebutkan penelitian pustaka atau kepustakaan merupakan penelitian yang dilakukan dengan menelaah karya-karya yang berkaitan dengan permasalahan yang dikaji serta mencatat bagian penting yang ada hubungannya dengan topik pembahasan (Yahya 2015, 231). Sumber data dalam penelitian ini adalah data sekunder yang berasal dari buku dan hasil penelitian yang relevan. Teknik yang akan digunakan untuk mengumpulkan data dalam penelitian ini adalah telaah kepustakaan, yaitu mencari data mengenai halhal yang berupa catatan, transkip, buku, surat kabar, majalah, internet dan sebagainya (Arikunto 1992, 200). 


\section{PEMBAHASAN}

\section{Kerangka Metodologi Ekonomi Islam}

Dalam pandangan Islam kebenaran dan kebaikan mutlak hanya berasal dari Allah, baik yang berbentuk ayat qauliyah ataupun kauniyah. Sebagian dari ayat qauliyah dapat secara langsung dipahami sebagai kebenaran, namun sebagian ayat lainnya masih memerlukan penafsiran untuk memahaminya. Disisi lain, kebenaran dapat bersumber dari fenomena alam semesta atau ayat kauniyah. Allah berfirman dalam Al-Qur'an Surah Al-Baqarah ayat 29:

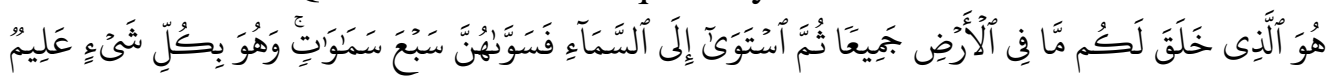

Artinya: "Dialah (Allah) yang menciptakan segala apa yang ada di bumi untukmu kemudian Dia menuju ke langit, lalu Dia menyempurnakannya menjadi tujuh langit. Dan Dia Maha Mengetahui segala sesuatu”.

Ayat kauniyah ini berfungsi sebagai pendukung dan penguat kebenaran yang disampaikan melalui ayat-ayat qauliyah. Dalam Al-Qur'an Allah memerintahkan manusia untuk membaca kejadian dialam semesta untuk menemukan kebenaran dengan petunjuk Al-Qur'an. Oleh karena itu, kebenaran ayat kauniyah masih dipengaruhi oleh penafsiran manusia terhadap fenomena sosial dan alam karena kebenaran empiris tidaklah bersifat mutlak.

Kebenaran yang disimpulkan melalui metode ilmiah dari fenomena alam tidak menyebabkan divergensi antara kata "kebenaran" dan "kebaikan". Tidak demikian halnya pada area ilmu sosial dimana ilmu ekonomi termasuk didalamnya. Kesalahan terbesar dari metodologi yang dikembangkan selama ini dalam ilmu ekonomi adalah mengidentikkan ekonomi dengan proses yang terjadi dalam ilmu fisika (Chapra 2000). Mekanisme hubungan antar berbagai variabel yang terbentuk dalam ilmu ekonomi dipercayai sebagai pola yang pasti. Anggapan tentang kepastian inilah yang telah menjebak ilmu ekonomi dalam perangkap determinisme. Ekonomi Islam merupakan manifestasi ajaran Islam dalam perilaku ekonomi, mulai penentuan tujuan kegiatan ekonomi, sikap, analisis, dan respons terhadap sosial dalam tataran empiris, perilaku ekonomi Islam secara parsial dapat dijumpai pada sekelompok masyarakat muslim maupun non muslim.

\section{Ilmu Pengetahuan Metodologi Ekonomi Islam}

Ilmu pengetahuan berusaha untuk menginternalisasi nilai-nilai agama dalam tradisi ilmiah dan membangun disiplin ilmu pengetahuan yang tidak terpisah dari doktrin dan prinsip agama (metafisika). Sumber ilmu pengetahuan tidak lagi dibatasi pada rasional akal dan pengalaman empiris saja, tetapi juga doktrin/ajaran agama yang bersumber dari Al-Qur'an dan Hadits (Furqani 2018, 26). Gerakan Islamisasi ilmu pengetahuan menjadikan body of knowledge atau disiplin ilmu kontemporer sebagai sasaran integrasi epistemologisnya. Karena disiplin ilmu moderen dibangun dari tradisi epistemologis yang tidak sesuai dengan prinsip Islam. Namun demikian, bukan berarti bahwa kita menolak disiplin ilmu ekonomi secara keseluruhan. Sebagiannya masih bisa diterima jika sesuai dengan prinsip Islam.

Islamisasi pengetahuan merupakan isu yang tidak bisa dilewatkan begitu saja dan telah lama diperbincangkan, termasuk di Indonesia. Banyak kalangan yang mencoba mengusung gagasan ini dan banyak pula yang mengkritiknya, namun tidak banyak yang memahaminya secara konseptual dalam konteks 
pandangan hidup dan peradaban Islam. Di antara bidang garap gagasan Islamisasi pengetahuan, ekonomi Islam adalah subjek kajian yang paling maju secara teoritis maupun praktis kendatipun masih berada di tahap awal perkembangan. Namun, sebagai ilmu, ekonomi Islam yang dewasa ini semakin banyak menarik minat orang untuk mengkajinya, ternyata masih sering disalah tafsirkan. Dengan kata lain, ekonomi Islam yang dibangun oleh para pencetusnya belum dapat dikatakan sebagai sebuah disiplin ilmu yang mapan, karena dipandang tidak ditemukan adanya bangunan pemikiran ekonomi yang utuh seperti halnya dalam ilmu ekonomi modern. Sementara itu, sebagian yang lain menganggap bahwa perkembangan studi ekonomi Islam tidak lain hanyalah sebagai reaksi sesaat dalam merespon modernisme.

Persepsi tersebut muncul disebabkan karena ilmu ekonomi Islam sekarang ini memang masih berada dalam tahap perkembangan dan hingga kini masih terus mencari formulasi teori yang benar-benar mapan. Beberapa masalah yang penting adalah munculnya debat metodologis yang mengiringi konstruksi teoritis ekonomi Islam. Namun, di sisi yang lain justru sudah banyak bermunculan institusiinstitusi (keuangan) Islam yang mengaplikasikan teori ke dalam praktek sebelum debat metodologi itu benar-benar diselesaikan (Hoetoro 2007, 3). Namun demikian, tidak dapat disangkal lagi bahwa berkembangnya studi ekonomi Islam ini dipicu oleh gerakan Islamisasi pengetahuan yang dengan intensif diaktifkan oleh Al-Faruqi (1982); Al-Attas (1993), dan sebagainya.

Banyak terdapat kerancuan dalam memaknai istilah Islamisasi pengetahuan (Islamization of Knowlegde). Sebagian menekankan bahwa perlunya definisi yang baku tentang istilah tersebut, sebagian lainnya hanya perlu definisi operasional dan sebagian lagi lebih mementingkan isi daripada redaksi teknis. Namun demikian, rupanya sebuah definisi yang jelas tetap diperlukan agar persepsi terhadap istilah ini tidak menjadi rancu. Istilah Islamisasi dapat diacu dari Al-Attas (1993, 44), yaitu pembebasan manusia dari pikiran-pikiran magis, mitologis, animastis dan tradisi nasional yang bertentangan dengan Islam serta penguasaan pikiran sekuler atas ide dan bahasa. Definisi tersebut dapat dipahami bahwa makna Islamisasi pengetahuan adalah usaha pembebasan pengetahuan dan cabang-cabang keilmuannya dari interpretasi yang sekuler menjadi selaras dengan worldview dan idealita Islam. Pada arah ini tampak jelas bahwa dalam proses Islamisasi, setiap pengembangan ilmu pengetahuan seharusnya merefleksikan worldview Islam.

Kelemahan dalam memahami worldview Islam ini sudah pasti akan menghasilkan produk-produk pengetahuan yang parsial. Definisi yang lebih praktis dikemukakan oleh Al-Faruqi $(1982,14)$ bahwa Islamisasi pengetahuan adalah sebuah proses untuk menuang kembali pengetahuan modern dan cabangcabang keilmuannya ke dalam tata nilai Islam. Istilah ini diantaranya untuk menjembatani dikotomi yang ada antara sistem pendidikan modern sekuler dengan sistem pendidikan tradisional Islam.

Sumber ilmu pengetahuan dalam Islam tidak terbatas hanya dari fakta empiris, pengalaman nyata atau hukum alam yang diamati dan dirasakan dalam kehidupan manusia, tetapi mencakup juga akal fikiran dan wahyu Tuhan. Epistemologi Islam mengenal sumber ilmu yang beragam yaitu wahyu, akal dan fakta/pengalaman yang berimplikasi kepada metodologi ilmiah untuk melahirkan ilmu pengetahuan dan teori serta kriteria kebenaran dan pembuktian kebenaran 
tidak sama dengan epistemologi konvensional dan dalam hal ini ekonomi konvensional (Furqani 2018, 28).

Selanjutnya, hasil dari proses ini harus diikuti oleh proses integrasi pengetahuan yang baru ke dengan pandangan dunia (worldview) dan tata nilai Islam. Menurut Ahmadiono (2003, 204) untuk merealisasikan dalam khazanah intelektualitas Islam yang menyelaraskannya hal ini, proses Islamisasi pengetahuan memerlukan tiga langkah utama, yaitu: (a) Penguasaan disiplin ilmuilmu modern yang diikuti oleh penilaian kritis atas metodologi, temuan ilmiah dan teori yang selaras dengan visi Islam. (b) Penguasaan tradisi ilmiah Islam disertai dengan evaluasi kritis pandangan tentang doktrin-doktrin agama, kebutuhan umat saat ini, dan kemajuan ilmu pengetahuan modern. (c) Sintesis kreatif antara warisan Islam dan pengetahuan modern sebagai lompatan kreatif untuk menjembatani kesenjangan ilmiah yang terjadi selama masa-masa panjang kevakuman pengembangan ilmu pengetahuan Islam.

Berangkat dari berbagai pengertian tersebut, maka dapat dikatakan bahwa Islamisasi pengetahuan, sepertinya lebih terfokus pada persoalan-persoalan epistemologi dan metodologi dalam membangun ilmu pengetahuan berdasarkan pada sumber-sumber Islam dan metode ilmu pengetahuan modern. Islamisasi adalah sebuah usaha pengembangan teori untuk merestorasi kegiatan-kegiatan ilmiah, terutama untuk ilmu-ilmu sosial ke arah penyatuan wahyu dan observasi dunia empiris. Kegiatan ini tidak sekedar melakukan penambahan atau pengurangan terhadap struktur ilmu pengetahuan, melainkan perlu adanya pengelolaan yang kreatif dalam pengembangan ilmu-ilmu sosial modern sesuai dengan visi, pandangan dunia dan tradisi keilmuan Islam.

Dengan demikian, hakikat Islamisasi pengetahuan adalah aktivitasaktivitas kecendekiaan yang sistematik dari ontologi dan epistemologi non Islam ke dalam Islam yang menjadi dasar perubahan metodologi pengembangan ilmu pengetahuan. Oleh karena itu, obyek utama Islamisasi adalah bagaimana membangun metodologi atau cara-cara "meng-Islamkan" ilmu-ilmu sosial modern karena disiplin ilmu pengetahuan ini dipandang mempengaruhi langsung cara pandang, pola pikir, dan gaya hidup kaum Muslimin.

Al-Faruqi, Ziauddin Sardar dan Al-Attas dipandang sebagai garda depan pengusung dan pengembang gagasan Islamisasi, meskipun mereka berbeda dalam metode dan strategi implementasinya. Al-Attas menyebut gagasan awalnya sebagai "dewesternisasi ilmu"; Al-Faruqi berbicara tentang "Islamisasi ilmu"; sedangkan Sardar tentang penciptaan suatu "sains Islam kontemporer" (Manan 2005, 24). Gagasan para pemikir tersebut tentu berbeda-beda, dan terkadang bahkan berseberangan, meskipun terkadang secara kurang cermat dilabeli sama dengan istilah "Islamisasi ilmu". Meski demikian, satu hal yang barangkali merupakan kelemahan bersama gagasan ini adalah bahwa ia tampaknya terutama digagas sebagai gagasan filosofis mengenai sains, dan hingga waktu cukup lama tak jelas benar bagaimana gagasan filosofis itu bisa dijadikan relevan dengan aktivitas ilmiah praktis. Kelemahan ini juga telah menyebabkan ia mudah, dan telah, disalahpahami. Al-Faruqi, sebenarnya hanya memformalkan gagasan yang sudah lama muncul sejak tahun 1960-an atau bahkan sejak 1930-an ketika alMaududi, Sayyid Qutb, dan lain-lainnya berbicara tentang aspek-aspek Islam dalam ekonomi.

Namun jika dirunut sejak akhir periode tersebut, maka inilah respon yang 
paling kredibel sebagai jawaban Islam terhadap modernitas, meskipun sampai sekarang ini belum berhasil mencapai bentuknya yang final. Al-Faruqi dalam "work-plan"nya menyebutkan sebab-sebab kemunduran kaum Muslimin di hampir semua lapangan kehidupan, baik di bidang politik, ekonomi dan religiocultural yang disebutnya sebagai "malaise of the ummah". Hal tersebut disebabkan karena mereka telah kehilangan visi dan kesalahan dalam sistem pendidikan yang dikembangkan. Meskipun tidak dielaborasi lebih jauh, Al-Faruqi menyinggung kelemahan visi ini sebagai sebab yang penting mengapa kaum Muslimin sekarang tidak lagi mampu menggali dan mengapresiasi warisan kekayaan intelektualitas para pendahulu mereka yang sebenarnya berperan strategis sebagai pijakan dasar alam modern. Sasaran Al-Faruqi adalah reformasi sistem pendidikan yang mendua. Di satu sisi, tradisional, dan di sisi yang lain, modern (sekuler) telah menjadi gabungan sebuah sistem pendidikan yang mampu mengintegrasikan pandangan dunia Islam dan capaian-capaian modernitas (AlFaruqi 1982, 1-5).

Namun demikian, Al-Faruqi berpendapat bahwa ilmu pengetahuan yang saat ini tengah berkembang tidak semuanya bertentangan dengan nilai-nilai Islam. Dengan demikian, Al-Faruqi menyarankan proses Islamisasi adalah melakukan penyaringan dari ilmu pengetahuan yang telah ada. Jika semua aspek ilmu tersebut bertentangan dengan nilai-nilai Islam maka otomatis ilmu tersebut tidak dapat dipakai dan dikembangkan lebih lanjut. Namun jika tidak ada unsur dalam suatu ilmu tersebut yang bertentangan dengan nilai-nilai Islam, sebaiknya dilakukan proses perpaduan dengan nilai-nilai Islam. Metode ini dianggap sebagai pendekatan terpadu penyimpulan syariah dan sosial (Safi 1996, 171).

Oleh karena itu, dalam karya awalnya tentang Islamisasi pengetahuan, ia menuangkan tahap-tahap pencapaian yang dikenal sebagai dua belas langkah dalam sebuah kerangka kerja (work-plan) yang berisikan tentang usaha penguasaan ilmu-ilmu pengetahuan modern dengan dibarengi penguasaan segenap warisan intelektualitas Islam sebagai proyek percontohannya (Al-Faruqi 1982, 3946). Terlepas dari banyaknya kritik yang diarahkan kepada work-plan tersebut jelas bahwa sasaran Al-Faruqi adalah bagaimana menjembatani konfrontasi antara tradisi Islam dan kemajuan barat.

Karya Al-Faruqi tentang Islamisasi ilmu pengetahuan yang banyak menjadi referensi para pemikir adalah Islamization of Knowlwdge: General Principles and Work-plan, yang diterbitkan oleh The International Institute of Islamic Thought. Karya Al-Faruqi ini banyak menjadi rujukan pakar lain dalam memahami dan mengembangkan Islamisasi ilmu pengetahuan. Hal ini disebabkan karena konsep Al-Faruqi dinilai sangat aplikatif dibandingkan dengan konsep AlAttas dan Sardar. Konsep Al-Faruqi secara teknis tidak menafikan ilmu pengetahuan yang saat ini sedang eksis yaitu keilmuan sekuler, yang dilakukan hanyalah pemilihan dan pemilahan apa yang sesuai dengan nilai-nilai Islam. Implementasi dari pemikiran Al-Faruqi ini terwujud dengan berdirinya International Islamic University (IIU) di Kuala Lumpur Malaysia dan Islamabad.

Di tempat lain, Al-Attas, tanpa menafikan faktor eksternal yang ada lebih menekankan pada kelemahan internal kaum Muslimin yang telah kehilangan "adab". Istilah ini mengacu pada efek sinergi antara tubuh, pikiran dan jiwa yang tidak seimbang karena kerancuan dalam memahami pengetahuan yang sejati (true knowledge) terhadap pengetahuan yang telah dirasuki oleh visi-visi barat 
(westernized). Tidak salah lagi bahwa tekanan Al-Attas disini adalah menyoroti persoalan apakah pengetahuan dan ilmu pengetahuan itu netral atau tidak. Dan memang, dalam karya-karyanya sepanjang periode 1978-1999, Al-Attas secara intensif menekankan pentingnya koneksi antara worldview (visi) Islam terhadap ilmu pengetahuan modern dan membuat perbandingannya dengan filsafat barat dan posisi teologinya. Dari sini, ia kemudian menegaskan ketidaknetralan ilmu pengetahuan modern (barat) dan karena itulah perlu dilakukan usaha Islamisasi. Menurutnya, kegagalan kaum Muslimin dalam memahami pengetahuan secara benar itulah yang menjadi sebab utama kemunduran.

Masalah terbesar yang dihadapi kaum Muslimin sekarang adalah bukan lenyapnya kekuasaan politik tetapi karena adanya korupsi yang akut dalam memaknai esensi pengetahuan, yang disebabkan oleh kerancuan internal dan dominasi pengaruh filsafat, sains, dan ideologi barat modern. Akibatnya, masyarakat kini kehilangan adab yang berimplikasi pada munculnya para pemimpin yang tidak cakap, tidak memiliki integritas moral dan standar intelektual atau spiritual Islam tetapi terus-menerus mengontrol urusan kehidupan umat Islam (Haneef 2005, 13).

Oleh karena itu, Al-Attas (1993) berpendapat bahwa proses Islamisasi haruslah menyeluruh dari filosofi, paradigma hingga proses pembelajarannya yang menyesuaikan dengan karateristik keilmuan Islam yang ada. Dengan mengetahui pandangan dunia Islam dan barat, maka proses Islamisasi akan bisa dilakukan. Sebab Islamisasi ilmu ekonomi melibatkan dua proses yang saling terkait (Armas 2005, 9-10): (a) Mengisolir unsur-unsur dan konsep-konsep kunci yang membentuk budaya dan peradaban barat dari setiap bidang ilmu pengetahuan modern saat ini, khususnya di dalam ilmu pengetahuan humaniora. Bagaimanapun juga, ilmu-ilmu alam, fisika dan aplikasinya harus di-Islamkan juga, khususnya dalam penafsiran-penafsiran akan fakta- fakta di dalam formulasi teori-teori. (b) Memasukkan unsur-unsur Islam beserta konsep-konsep kunci dalam setiap bidang dari ilmu pengetahuan saat ini yang relevan.

Pemikir-pemikir modern lainnya juga mendukung pendapat Al-Attas, seperti Brohi melihat perlunya menyukseskan proyek Islamisasi pengetahuan ini karena pengetahuan modern dengan berbagai macam cabang ilmunya didasarkan pada kerangka yang tidak selaras dengan worldview Islam. Sementara itu, Ausaf Ali menegaskan bahwa setiap sistem ilmu pengetahuan sosial (social sciences) dan perilaku manusia sesungguhnya memerlukan sebuah kerangka konseptual atau teori umum tentang masyarakat, dan sangat jelas bahwa tidak semua ilmu pengetahuan modern kompatibel dengan kerangka konseptual Islam (Haneef 2005, 14-15).

Al-Alwani mendukung pernyataan ini dengan menegaskan bahwa ilmu pengetahuan modern kini telah menjadi pengetahuan yang sangat positivistik, karena hanya membaca satu buku (alam semesta) sehingga tidak sesuai dengan kerangka pengetahuan Islam yang perlu membaca dua buku, yaitu wahyu dan alam semesta. Menurutnya bahwa ilmu sosial dan humaniora kontemporer adalah produk dari pikiran-pikiran barat yang memiliki filosofi, metodologi, tujuan, penjelasan terhadap perilaku manusia, dan pandangan kehidupan sendiri yang berseberangan dengan perspektif dan metodologi ilmiah Islam hanya dengan melalui "pembacaan dua buku" itulah yang akan menyeimbangkan pemahaman manusia terhadap realitas. Jika gagal melakukan hal itu, maka dipastikan bahwa 
sistem pendidikan yang ada tidak akan dapat menghasilkan manusia-manusia terdidik selain hanya para juru tulis dan operator teknis (Haneef 2005, 14-15). Meskipun sudah banyak cendekiawan Muslim yang mendukung perlunya Islamisasi pengetahuan, namun debat dan polemik ternyata masih sering dijumpai. Perdebatan yang sering muncul adalah seputar masalah definisi, metodologi dan hasil-hasil yang telah dicapai oleh Islamisasi.

\section{Kembali Kepada Falsafah Ilmu Islam}

Kata ilmu berasal dari bahasa Arab 'ilm ('alima-ya'lamu-'ilm), yang berarti pengetahuan (al-ma'rifah), kemudian berkembang menjadi pengetahuan tentang hakikat sesuatu yang dipahami secara mendalam. Dari asal kata 'ilm ini selanjutnya di-Indonesia-kan menjadi "ilmu" atau "ilmu pengetahuan". Dalam perspektif Islam, ilmu merupakan pengetahuan mendalam hasil usaha yang sungguh-sungguh (ijtihād) dari para ilmuwan muslim ('ulamā'/mujtahīd) atas persoalan-persoalan duniawī dan $u k h r \bar{a} w \bar{\imath}$ dengan bersumber kepada wahyu Allah.

Al-Qur'an dan Al-Hadits merupakan wahyu Allah yang berfungsi sebagai petunjuk (hudan) bagi umat manusia, termasuk dalam hal ini adalah petunjuk tentang ilmu dan aktivitas ilmiah. Al-Qur'an memberikan perhatian yang sangat istimewa terhadap aktivitas ilmiah. Terbukti, ayat yang pertama kali turun berbunyi: "Bacalah, dengan [menyebut] nama Tuhanmu yang telah menciptakan". Membaca, dalam artinya yang luas, merupakan aktivitas utama dalam kegiatan ilmiah. Disamping itu, kata ilmu yang telah menjadi bahasa Indonesia bukan sekedar berasal dari bahasa Arab, tetapi juga tercantum dalam Al-Qur'an. Kata ilmu disebut sebanyak 105 kali dalam Al-Qur'an. Sedangkan kata jadiannya disebut sebanyak 744 kali. Kata jadian yang dimaksud adalah; 'alima (35 kali), ya'lamu (215 kali), i’làm (31 kali), yu’lamu (1 kali), 'alìm (18 kali), ma'lūm (13 kali), 'ālamìn (73 kali), 'alam (3 kali), 'a'lam (49 kali), ‘alìm atau 'ulamā' (163 kali), 'allām (4 kali), 'allama (12 kali), yu'limu (16 kali), 'ulima (3 kali), mu'allām (1 kali), dan ta'allama (2 kali).

Selain kata 'ilmu, dalam Al-Qur'an juga banyak disebut ayat-ayat yang, secara langsung atau tidak, mengarah pada aktivitas ilmiah dan pengembangan ilmu, seperti perintah untuk berpikir, merenung, menalar, dan semacamnya. Misalnya, perkataan 'aql (akal) dalam Al-Qur'an disebut sebanyak 49 kali, sekali dalam bentuk kata kerja lampau, dan 48 kali dalam bentuk kata kerja sekarang. Salah satunya adalah firman Allah dalam Al-Qur'an Surah Al-Anfal ayat 22:

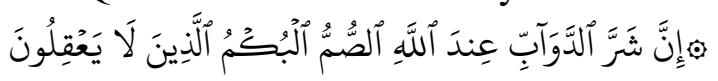

Artinya: "Sesungguhnya makhluk bergerak yang bernyawa yang paling buruk dalam pandangan Allah ialah mereka yang tuli dan bisu (tidak mendengar dan memahami kebenaran) yaitu orang-orang yang tidak mengerti”.

Kata fikr (pikiran) disebut sebanyak 18 kali dalam Al-Qur'an, sekali dalam bentuk kata kerja lampau dan 17 kali dalam bentuk kata kerja sekarang. Salah satunya adalah; "...mereka yang selalu mengingat Allah pada saat berdiri, duduk maupun berbaring, serta memikirkan kejadian langit dan bumi”. Tentang posisi ilmuwan, terdapat dalam Al-Qur'an surah Al-Mujadalah ayat 11:

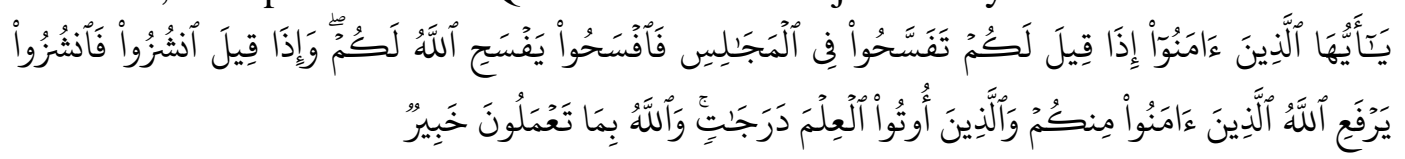


Artinya: "Wahai orang-orang yang beriman! Apabila dikatakan kepadamu, "Berilah kelapangan di dalam majelis-majelis," maka lapangkanlah, niscaya Allah akan memberi kelapangan untukmu. Dan apabila dikatakan, "Berdirilah kamu," maka berdirilah, niscaya Allah akan mengangkat (derajat) orang-orang yang beriman di antaramu dan orang-orang yang diberi ilmu beberapa derajat. Dan Allah Mahateliti apa yang kamu kerjakan".

Di samping al-Qur'an, dalam Hadits Nabi banyak disebut tentang aktivitas ilmiah, keutamaan penuntut ilmu/ilmuwan, dan etika dalam menuntut ilmu. Misalnya, hadits-hadits yang berbunyi;

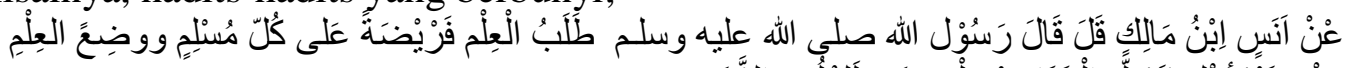

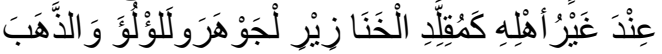

Artinya: "Dari Anas bin Malik ia berkata, Rasulullah SAW, bersabda: Mencari ilmu itu wajib bagi setiap muslim, memberikan ilmu kepada orang yang bukan ahlinya seperti orang yang mengalungi babi dengan permata, mutiara, atau emas" (HR. Ibnu Majah).

Kemudian hadits riwayat Bukhari Muslim yang artinya: "Menuntut ilmu merupakan kewajiban setiap muslim dan muslimah". Hadits riwayat Turmudzi yang artinya: "Barang siapa keluar rumah dalam rangka menuntut ilmu, malaikat akan melindungi dengan kedua sayapnya". Hadits riwayat Muslim yang artinya: "Barang siapa keluar rumah dalam rangka menuntut ilmu, maka ia selalu dalam jalan Allah sampai ia kembali". Hadits riwayat Turmudzi yang artinya: "Barang siapa menuntut ilmu untuk tujuan menjaga jarak dari orang-orang bodoh, atau untuk tujuan menyombongkan diri dari para ilmuwan, atau agar dihargai oleh manusia, maka Allah akan memasukkan orang tersebut ke dalam neraka".

Besarnya perhatian Islam terhadap ilmu pengetahuan, menarik perhatian Franz Rosenthal, seorang orientalis, dengan mengatakan: "Sebenarnya tak ada satu konsep pun yang secara operatif berperan menentukan dalam pembentukan peradaban Islam di segala aspeknya, yang sama dampaknya dengan konsep ilmu. Hal ini tetap benar, sekalipun di antara istilah-istilah yang paling berpengaruh dalam kehidupan keagamaan kaum muslimin, seperti "tauhîd" (pengakuan atas keesaan Tuhan), "al-dîn” (agama yang sebenar-benarnya), dan banyak lagi katakata yang secara terus menerus dan bergairah disebut-sebut. Tak satupun di antara istilah-istilah itu yang memiliki kedalaman dalam makna yang keluasan dalam penggunaannya, yang sama dengan kata ilmu itu. Tak ada satu cabangpun dalam kehidupan intelektual kaum muslimin yang tak tersentuh oleh sikap yang begitu merasuk terhadap "pengetahuan" sebagai sesuatu yang memiliki nilai tertinggi, dalam menjadi seorang muslim.

Penjelasan Al-Qur'an dan Al-Hadits tersebut menunjukkan bahwa paradigma ilmu dalam Islam adalah teosentris. Karena itu, hubungan antara ilmu dan agama memperlihatkan relasi yang harmonis, ilmu tumbuh dan berkembang berjalan seiring dengan agama. Karena itu, dalam sejarah peradaban Islam, ulama hidup rukun berdampingan dengan para ilmuwan. Bahkan banyak ditemukan para ilmuwan dalam Islam sekaligus sebagai ulama. Misalnya, Ibn Rusyd disamping sebagai ahli hukum Islam pengarang kitab Bidāyah al-Mujtahìd, juga seorang ahli kedokteran penyusun kitab al-Kullīyāt fì al-Thibb (Kosim 2008, 122-124). Berdasarkan uraian tersebut, menunjukkan bahwa sumber dan metode ekonomi dalam Islam adalah Al-Qur'an dan Al-Hadits, dimana keduanya merupakan pedoman hidup bagi kaum muslimin. 


\section{KESIMPULAN}

Sebagai sebuah disiplin ilmu, ekonomi islam harus memiliki bangunan keilmuan yang lengkap seperti body of knowledge yang mantap, metodologi untuk melahirkan teori, teori yang menjelaskan doktrin dan realitas ekonomi serta akumulasi dan sistemasi ilmu dalam ekonomi Islam sebagai sebuah body of knowledge. Metodologi ekonomi Islam harus dibangun berdasarkan prinsip epistemologi Islam yang mengakui wahyu Tuhan (al-wahy) dalam bentuk alQur'an dan Al-Hadits sebagai sumber ilmu pengetahuan, di samping fakta empiris dan akumulasi pengalaman manusia (facts) dan penalaran akal (intellectual reasoning). Metodologi ekonomi Islam mempunyai pendekatan yang menyatukan (unified approach) ketiga sumber ilmu tersebut. Ini bermaksud tidak ada dikotomi antara 'fakta' (facts) dan 'nilai' (values), realita objektif (objective reality) dan perasaan-emosi subjektif (subjective emotions) atau nilai-nilai normatif (normative values) seperti dalam epistemologi ilmu-ilmu modern.

Metodologi ekonomi Islam bertujuan melahirkan kriteria ilmiah, prinsip dan standar, atau rasionalisi, argument dan justifikasi untuk melahirkan sebuah teori dan membuktikan kebenarannya mana yang valid dan tidak valid, benar dan salah; dan serangkaian metode, teknik, prosedur ilmiah yang perlu ditempuh dalam melahirkan teori dan membuktikan kebenaran teori tersebut. Biasanya ini dihasilkan setelah jelas kriteria ilmiah dan kebenaran.

Kerangka metodologis ekonomi Islam adalah kebenaran dan kebaikan, metodologi ilmu alam, metodologi ilmu sosial dan objek ekonomi Islam. Para ilmuwan yang terlibat dalam gerakan mengembangkan ekonomi Islam mempunyai beberapa pendekatan yang merefleksikan perbedaan metodologi, sepeti (1) metodologi usul fiqh dalam mengembangkan ekonomi Islam, (2) pluralisme metodologi dalam mengembangkan ekonomi Islam dan (3) metodologi Islamisasi ilmu pengetahuan.

\section{DAFTAR PUSTAKA}

Ahmadiono, Ahmadiono. 2003. "Islamisasi Ilmu Pengetahuan Dalam Bidang Ekonomi (Studi atas Gagasan Islamisasi Ilmu Pengetahuan Al-Faruqi dan Relevansinya dalam Bidang Ekonomi)." Antologi Kajian Islam.

Al-Attas, Syed Muhammad Naquib. 1993. Islam and Secularism. Kuala Lumpur: ISTAC.

Al-Faruqi, Ismail Raji. 1982. Islamisasi Ilmu Pengetahuan, Terjemahan. Anas Mahyudin. Bandung: Pustaka.

Arikunto, Suharsimi. 1992. Prosedur Penelitian Suatu Pendekatan Praktik. Jakarta: PT Rineka Cipta.

Armas, Adnin. 2005. "Westernisasi dan Islamisasi Ilmu." Jurnal Islamia 2 (6): $15-17$.

Beik, Irfan Syauqi. 2016. "Islamisasi Ilmu Ekonomi." ISLAMICONOMIC: Jurnal Ekonomi Islam 7 (2): 183-204. https://doi.org/10.32678/ijei.v7i2.40.

Chapra, M. Umer. 2000. Islam dan Tantangan Ekonomi. Jakarta: Gema Insani.

Fanani, Muhyar. 2008. Metodologi Studi Islam, Aplikasi Sosiologi Penetahuan Sebagai Cara Pandang. Yogyakarta: Pustaka Pelajar. 
Furqani, Hafas. 2018. Metodologi Ekonomi Islam (Membangun Paradigma dan Format Keilmuan). Banda Aceh: UIN Ar-Raniry.

Haneef, Mohammed Aslam. 2010. Pemikiran Ekonomi Islam Kontemporer (Analisis Komparatif Terpilih). Terj. Suherman Rosyidi. Edisi 1. Buku 1. Jakarta: PT. Raja Grafindo Persada.

Hassan, Zubair. 1998. "Islamization of Knowledge: Issue and Agenda." IIUM Journal of Economics and Management 6 (2).

Hoetoro, Arif. 2007. Ekonomi Islam, Pengantar Analisis Kesejarahan dan Metodologi. Malang: BPFE UNIBRAW.

Kosim, Muhammad. 2008. "Guru dalam Perspektif Pendidikan Islam." Journal STAIN Pamekasan Tadrîs 3 (2).

Manan, Bagir. 2005. Menyongsong Fajar Otonomi Daerah. Yogyakarta: Pusat Studi Hukum.

Nahriyah, Syafa'atun. 2018. "Metodologi dalam Ekonomi Islam." Maro: Jurnal Ekonomi Syariah dan Bisnis 1 (1): 12-24. https://jurnal.unma.ac.id/index.php/Mr/article/view/858.

Nazir, Moh. 1988. Metodologi Penelitian. Jakarta: Ghalia Indonesia.

Partanto, Pios A., and M. Dahlan Al-Barry. 1994. Kamus Ilmiyah Populer. Surabaya: Penerbit Arkola.

P3EI. 2012. Ekonomi Islam. Jakarta: PT. Raja Grafindo Persada.

Safi, Louay. 1996. The Foundation of knowledge: A Comparative Study in Islamic and Western Methods of Inquiry. Malaysia: IIUM \& IIIT.

Sari, Milya, and Asmendri Asmendri. 2020. "Penelitian Kepustakaan (Library Research) dalam Penelitian Pendidikan IPA.” Natural Science: Jurnal Penelitian Bidang IPA dan Pendidikan IPA $6 \quad$ (1). https://ejournal.uinib.ac.id/jurnal/index.php/naturalscience/article/view/15 55.

Yahya, Usman. 2015. "Konsep Pendidikan Anak Usia Sekolah Dasar (6-12) Tahun Di Lingkungan Keluarga Menurut Pendidikan Islam.” Islamika: Jurnal Ilmu-ilmu Keislaman $15 \quad$ (2): 227-244. https://ejournal.iainkerinci.ac.id/index.php/islamika/article/view/50.

Zed, Mestika. 2008. Metode Penelitian Kepustakaan. Jakarta: Yayasan Obor Indonesia. 